\title{
Swelling Characteristics of Saudi Tayma Shale and Consequential Impact on Light Structures
}

\author{
Muawia A. Dafalla and Mosleh A. Al-Shamrani \\ Department of Civil Engineering, King Saud University, Riyadh 12372, Arabic
}

\begin{abstract}
Expansive soils in Saudi Arabia have received wide attention in recent decades, following the rapid urbanization of rural and agricultural parts of the country. Tayma expansive shale inflicted serious damages to light structures, roads and boundary walls. This research is aimed at studying the engineering characteristics of the shale at this area including the basic geotechnical parameters as well as swelling behavior under oedometric loading conditions. The engineering properties were determined and compared to the local and international characterization charts. Mineralogy study using x-ray diffraction was conducted to investigate clay minerals present. The swell percent and the swelling pressure of the shale were investigated for samples prepared at different initial moisture contents and various dry densities. A close-up view of damages caused by the expansive shale in the town is highlighted and measures to reduce the risk of potential swelling distress for future constructions are presented.
\end{abstract}

Key words: Swell, characterization, shale, clay.

\section{Introduction}

Expansive soil is a disaster for the light construction industry in developing and underdeveloped countries. The problem is diagnosed since more than five decades and yet the treatment is not well established. Understanding the mechanism of heave and the factors affecting the swelling behaviour was studied extensively. The swelling of soils, in general, is due to the presence of expanding clay minerals, hydration of cations on clay surfaces, and release of intrinsic stresses caused by overconsolidation or consolidation of soils [1]. Works covering nano to microfabric features of clay to well documented engineering properties and behaviour is now present in the literature. How to utilize this wealth of information in practice is the today's challenge for practicing geotechnical engineers. It is very essential to geotechnical engineer to know what investigations shall be performed and what parameters need to be determined. The solutions to be applied for

Corresponding author: Muawia A. Dafalla, assistant professor, geotechnical consultant, research field: geotechnical engineering. E-mail: mdafalla@gmail.com. specific area or case cannot be effectively modeled as it involves many parameters. Shortly after expansive soil was recognized, numerous approaches on characterization and prediction of the degree of expansion were made [2]. Classification based on liquid limit, plasticity index, colloid content, shrinkage limit, and free swell was introduced by several researchers and entities [3, 4]. Table 1 is compiled to show the general ranges as obtained by some researchers.

\section{The Studied Area}

Saudi Arabia is a large country located within an arid and semi-arid zone, spanning over north latitudes from 20 degrees to 30 degrees and East longitudes from 34 degrees to 50 degrees. The subsurface soil formation is dominantly desert sand intermixed with alluvial deposits of silt, clay and gravel mostly eroded from parent rock formation. Extensive clay and clay rich soil were reported along the wadis and depressions (Fig. 1). Clay shale is encountered exposed or at a shallow level for most of the north and north-west parts of the Kingdom. Based on the extended experience of the authors, four different forms of swelling material were encountered 
Table 1 Expansion as classified based on simple index properties.

\begin{tabular}{lllll}
\hline \multirow{2}{*}{ Degree of expansion } & Liquid limit (\%) & Plasticity index "PI" (\%) & Shrinkage limits (\%) & \multirow{2}{*}{ Free swell index (\%) [4] } \\
& Chen [2] & Holtz and Gibbs [3] & Holtz and Gibbs [3] & \\
\hline Very high & $>60$ & $\geq 32$ & $\leq 10$ & $>200$ \\
High & $40-60$ & $23-45$ & $6-12$ & $100-200$ \\
Medium & $30-40$ & $12-34$ & $8-18$ & $50-100$ \\
Low & $\leq 20$ & $>13$ & $<50$ \\
\hline
\end{tabular}

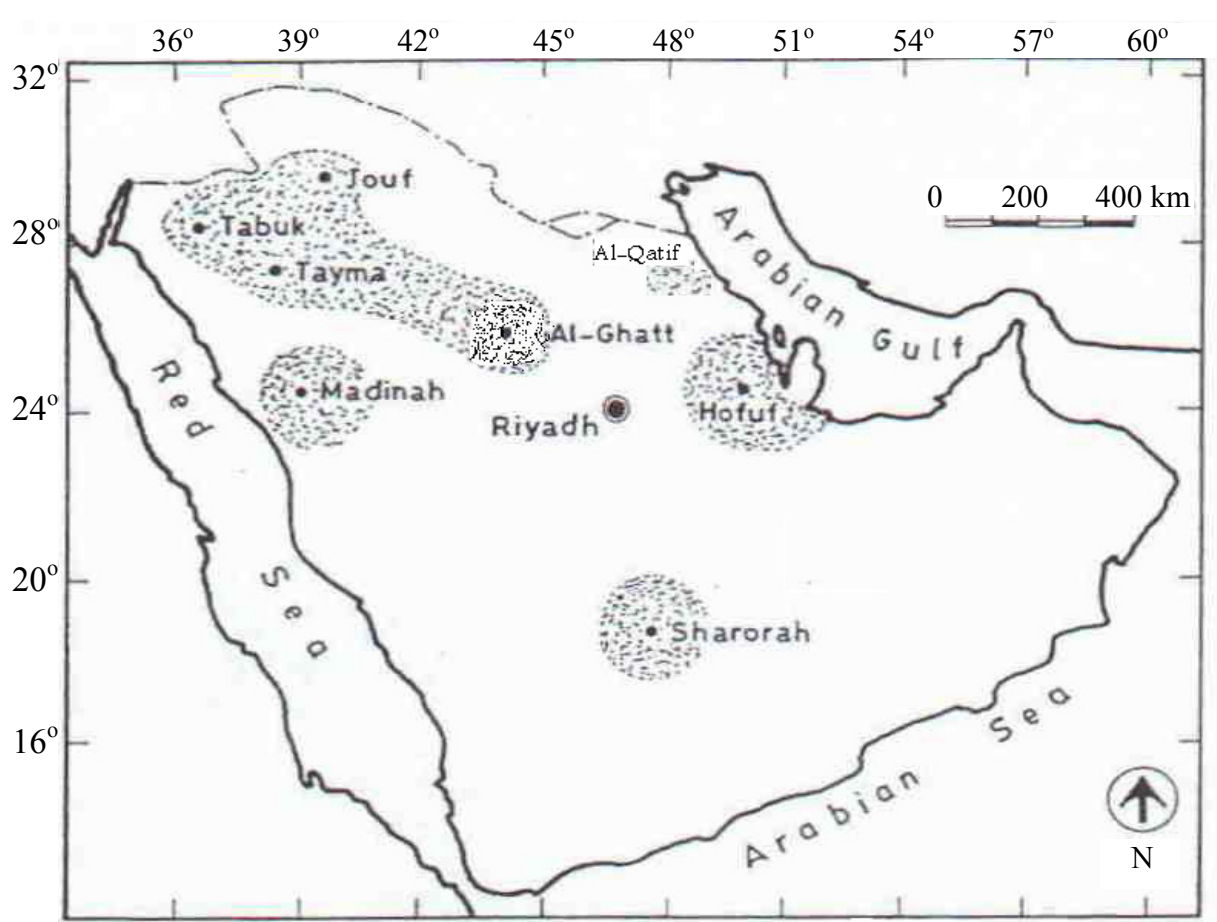

Regions with expensive formations

Fig. 1 Expansive soils in Saudi Arabia.

throughout the country as follows.

\subsection{Shale Material}

The shale is a fine grained weak rock composed of sedimentary deposits mainly clay or silt, oriented and laminated, flaky in nature, often referred to as silty shale or clayey shale. The mineralogy of the shale includes basic clay and non-clay minerals. This type is abundant in Tabuk, Al Joaf, Alghat and Tayma region. The quality of shale varies from place to place. Very hard in Tayma and weak to highly fractured at AlGhat District.

\subsection{Calcareous Clay Material}

The calcareous clay material is calcium carbonate rich clay, sedimentary deposits mainly encountered at the east coast and eastern parts of Saudi Arabia. This clay is found as thin to thick layers with interbeds of sand or calcareous deposits. The mineralogy of the clay includes smectite group minerals, calcite, quartz and other non-clay minerals. This type is abundant in the area of $\mathrm{Al}$ Hofuf and $\mathrm{Al}$ Qatif regions.

\subsection{Greenish Silty Clay}

The green silty clay material is a sedimentary deposits overlying the ingenious rock to the west and north wet of the Kingdom. Thickness of this formation may go beyond $20 \mathrm{~m}$. This is encountered at $\mathrm{Al}$ Madinah Al Munawara and its surroundings. The main minerals reported for this clay include quartz, feldspar, 
smectite, calcite, kaolinite and chlorite.

\subsection{Reddish Silty Clay}

The red silty clay material is a combination of wind-blown and alluvial deposits. This particular type of clay is reported in the southern region. This is mainly encountered at Sharoura and Najran. Minerals of quartz and feldspar as well as basic clay minerals make up the reddish silty clay of Saudi Arabia. This type is not limited to the southern part and can be noted in scattered spots within the kingdom.

The Taymasilty shale material is clearly of low degree of expansion if compared to these ranges. The troubles and upheaval distress given by this shale to light structures in Tayma indicate that these classifications shall be used as a guide only. Direct measurement testing methods shall be considered to assess the actual swelling likely to take place.

Chen [5] considered a liquid limit of less than 30 classifies the expansivity as low. No specific lower point is stated to distinguish non-expansive from low expansive clays. The Bureau of Indian Standards suggested 20 as a minimum value to consider a soil for expansivity [6].

It is very important to note that the terms heave, swell potential and swell percent are all related to specific testing arrangements and do not predict the actual amount of movement on site. These indices can be used for comparison and characterization but the actual upheaval movement can only be estimated using field tests under actual design loads. The swelling pressure test results obtained in the laboratory can be useful but the results need to be adjusted to simulate insitu set up. This adjustment requires knowledge of the subsurface strata, moisture variations, performance of existing structures in the subject area and the level of confinement. The importance of the structure, drainage efficiency and tolerable risk level may also be taken into account. Experienced practicing engineers if supplied with accurate laboratory measurements and information can end up with an appropriate decission on the swelling pressure value to be used in the design. Erzin and Erol [7] claimed that there is a direct relationship between the swell pressure and the suction measured using thermocouple psychrometer technique for statically compacted specimens. Soils stablized with cement or lime can still have high suction while the swelling behaviour is controlled. This can lead to a statement that high suction does not imply high swelling potential but highly expansive soils is expected to have high suction values. Bond and interparticle cementation is likely to reduce the expansion without affecting the suction significantly. A single test on naturally occuring clay may not be conclusive and further investigation need to be carried out. The effect of varyation of moisture content and dry density are two main parameters needed to establish practical ranges of swell pressure and swell potential. A minimum of three points for dry density and moisture content will be sufficient to estimate ranges of the swelling parameters. In addition to these two factors the geotechnical engineer need to have a look in bedding and the nature of the substrata, active zone and groundwater level to take a decission. The role or influence of the water content and the dry density on expansive clays is significant and important factor and must be supplied before a design swell pressure or swell potential is established. Al-Shamrani and Al-Muhaidib [8] conducted several triaxial swell tests using a stress path triaxial cellfor evaluating the swell behaviour under multi-dimensional loading conditions. The results of these tests were compared with the volume changes observed forsamples tested under identical initial conditions in the oedometer. The triaxial swell tests when compared to field tests provided reasonable estimatesof the measured field heaves in comparison to the oedometertests which yielded conservative predictions.

Researchers spent quite a time in establishing relationships between index properties such as liquid 
limit, plasticity index, natural moisture content, etc..These emperical procedures were found to be of local validity and rarely applicable to soils of different mineralogy. The good thing is that such formulas can be established from few laboratory tests. Heave prediction formulas were based on variable laboratory testing conditions and non-uniform procedures. Examples of heave equations based on moisture content or dry density is given by Vijayvergiya et al. [2]:

$\log S_{p}=0.0833\left(0.44 L L-w_{o}+5.5\right)$

$\log S_{p}=0.0526 \gamma_{d}+0.033 L L-6.8\left(\gamma_{d}\right.$ in $\left.\mathrm{lb} / \mathrm{ft}^{3}\right)(2)$

Where, $S_{p}$ is the percent swell, $w_{o}$ is the moisture content, $\gamma_{d}$ is the dry density expressed in $\mathrm{lb} / \mathrm{ft}^{3}$ and $L L$ is the liquid limit. Example of swell pressure $\left(P_{s}\right)$ prediction equation is given by Komornik and David [9] as:

$$
\begin{array}{r}
\log P_{s}=-2.132+0.0208 L L+0.000665 \gamma_{d}- \\
0.0269 w_{o}\left(\gamma_{d} \text { in } \mathrm{Kg} / \mathrm{m}^{3}\right)
\end{array}
$$

Nayak and Christensen[10] produced a prediction model for the swelling pressure (measured in psi) based on the PI (plasticity index), (C) clay content, and the $\left(w_{o}\right)$ moisture content:

$$
P S=3.5817 \times 10^{-2}(P I)^{1.12}\left(C / w_{o}\right)^{2}+3.7912
$$

The current study is performed for Tayma town located to the north west of great Nafud sedimentary basin. Subsurface formation in Tayma consists of hard to very hard laminated shale with possible inclusions of sandstone. This shale is rich in silt content and has low index properties. Al Rowda district, the heart of the town and where all governmental buildings are located is the most affected part and showed several distress and cracks within single story buildings, walkways and boundary walls. South and west parts of Tayma are underlain by sandstone and did not show any problems to construction. Groundwater was not encountered within top $20 \mathrm{~m}$ but water level due to irrigation, seepage and rainfall cause water level to rise close to ground surafce level.

\section{Experimental Work}

Two clay samples were collected from two sources in Tayma town in Saudi Arabia. These are referred to as trench site and a hospital site both located at Rawoda district. A range of index and classification tests were carried out and compared to works carried out by others. Table 2 summaries the test results. Standard proctor test was carried out in accordance with ASTM D698 for a sample from the trench site. Fig. 2 presents the grain size distribution including Hydrometer for Tayma shale. The maximum dry density obtained was $18.3 \mathrm{kN} / \mathrm{m}^{3}$ at an optimum moisture content of $14.6 \%$ (Fig. 3).

The free swell index of Tayma Hospital site and Trench site were found to be $18.518 \%$ and $42.22 \%$, respectively.Table 3 presents the free swell data.

Table 2 Geotechnical and index properties of Tayma Shale.

\begin{tabular}{llll}
\hline Soil properties & Trench sample & Hospital sample & Dhowian et al. [1] \\
\hline LL (liquid limit) (\%) & 33.8 & 35 & 38 \\
PL (plastic limit) (\%) & 25.4 & 26.7 & 25 \\
PI (plasticity index) (\%) & 8.4 & 8.3 & 13 \\
SL (shrinkage limit) (\%) & 24.91 & 20.63 & 20 \\
Gs (specific gravity) & 2.71 & 2.77 & 2.75 \\
Dry unit weight (kN/m ${ }^{3}$ ) & 23.2 & 23.2 & 19.4 \\
Natural moisture content (\%) & 1.6 & 1.6 & 2.3 \\
Gravel (\%) & 0.4 & 0.3 & 0 \\
Sand (\%) & 2.4 & 4.14 & 9 \\
Silt (\%) & 64.2 & 70.56 & 68 \\
Clay (\%) & 33 & 25 & 23 \\
\% passing sieve \# 200 & 97.20 & 95.56 & 91 \\
USCS (soil classification) & ML & ML & CL-ML \\
\hline
\end{tabular}




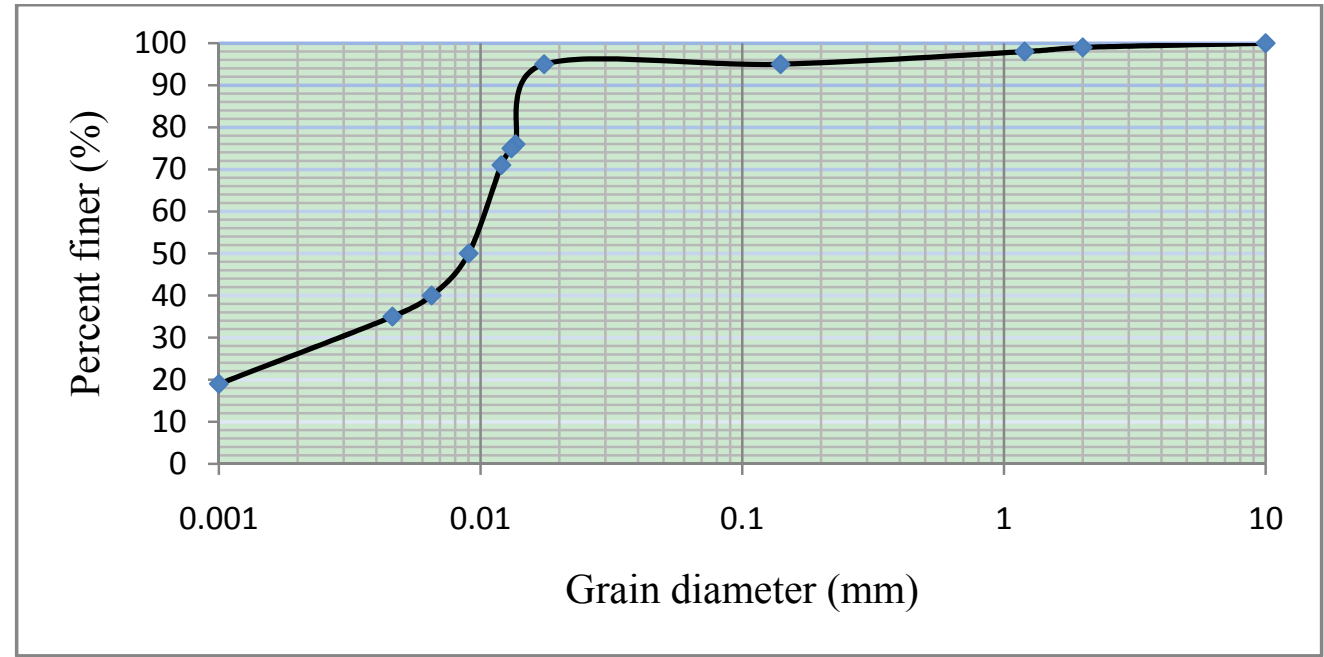

Fig. 2 Grain size distribution curve for Tayma shale (hospital site).

Table 3 Free swell tests of two samples.

\begin{tabular}{lllllll}
\hline \multirow{2}{*}{ Sample location } & \multicolumn{2}{c}{ Water } & & \multicolumn{2}{c}{ Kerosene } & \multirow{2}{*}{ Differential free swell index $(\%)$} \\
\cline { 2 - 3 } & Tube reference & Volume $\left(\mathrm{cm}^{3}\right)$ & & Tube reference & Volume $\left(\mathrm{cm}^{3}\right)$ & \\
\hline Hospital site & 1 & 16 & & 5 & 13.5 & 18.518 \\
Trench site & 3 & 16 & 11 & 11.25 & 42.22 \\
\hline
\end{tabular}

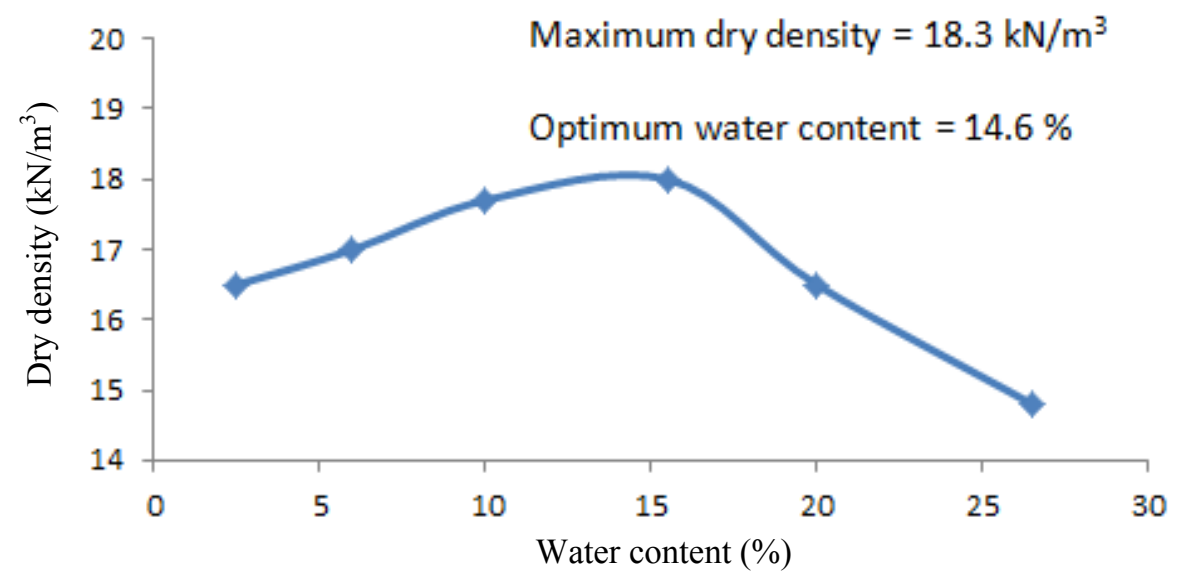

Fig. 3 Standard compaction test curve for Tayma shale (Trench site).

Fig. 4 presents a difractogram for Tayma Shale using utilizing SHIMADZU XRD-7000 setup at $40 \mathrm{Kv} \mathrm{Cu} \mathrm{K}$ alpha radiation source and a scanning speed of 2 degrees/minute.

The mineralogy as observed in $\mathrm{x}$-ray diffraction confirmed the presence of smectite group minerals as well as kaolinite and illite. Non-clay minerals including calcite, quartz and feldspar were noted.

The swell percent measured as percentage increase in a sample height was investigated for three different moisture content. These are 5, 10 and $17.5 \%$. The samples were prepared from crushed shale compacted to identical density of $18 \mathrm{kN} / \mathrm{m}^{3}$. The tests were performed in one dimensional odometers. Fig. 5 shows the swell percent variation with initial moulding moisture content. The influence of moisture content on the swelling pressure was also investigated. Fig. 6 shows the measured swelling pressure at different moisture content values. Fig. 7 shows the measured swelling pressure at different initial dry density values. 


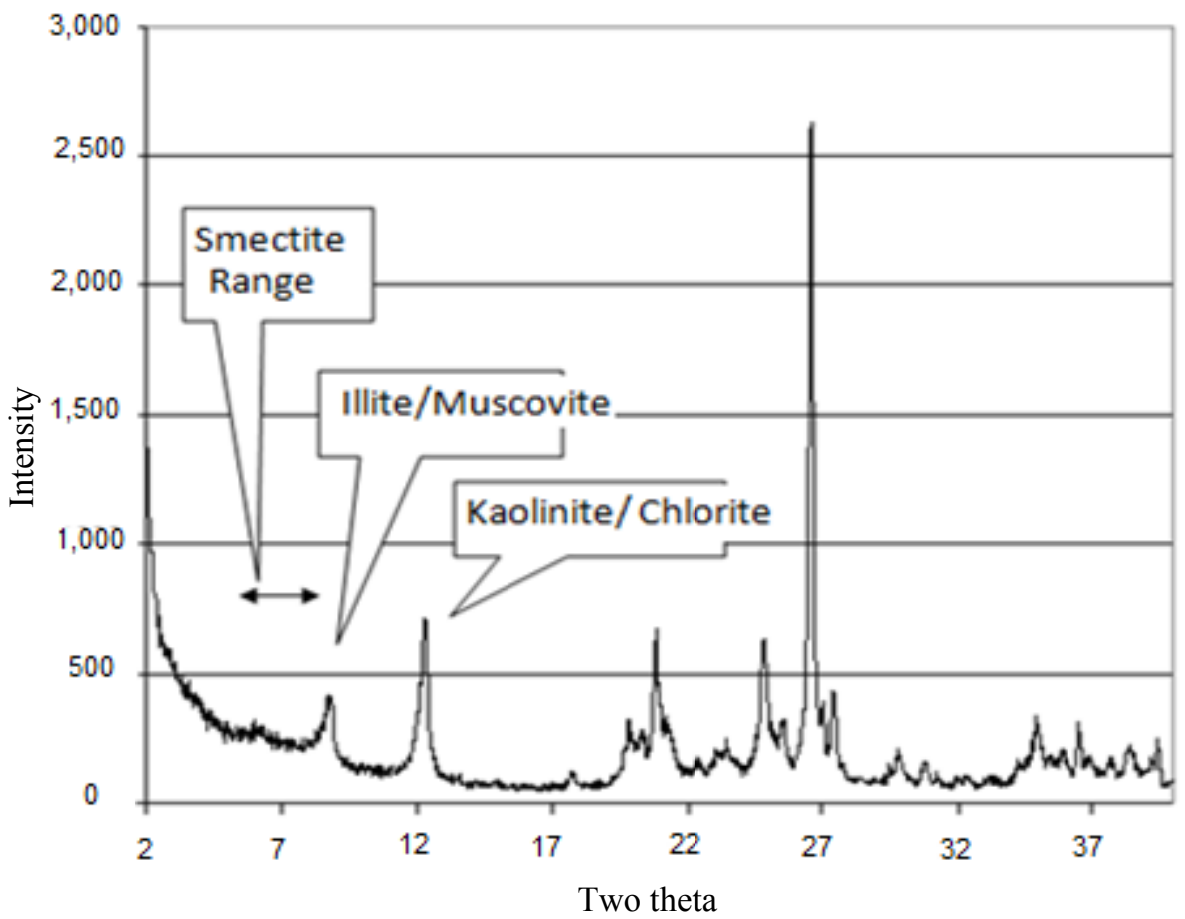

Fig. 4 X-ray diffraction of Tayma shale (Trench site).

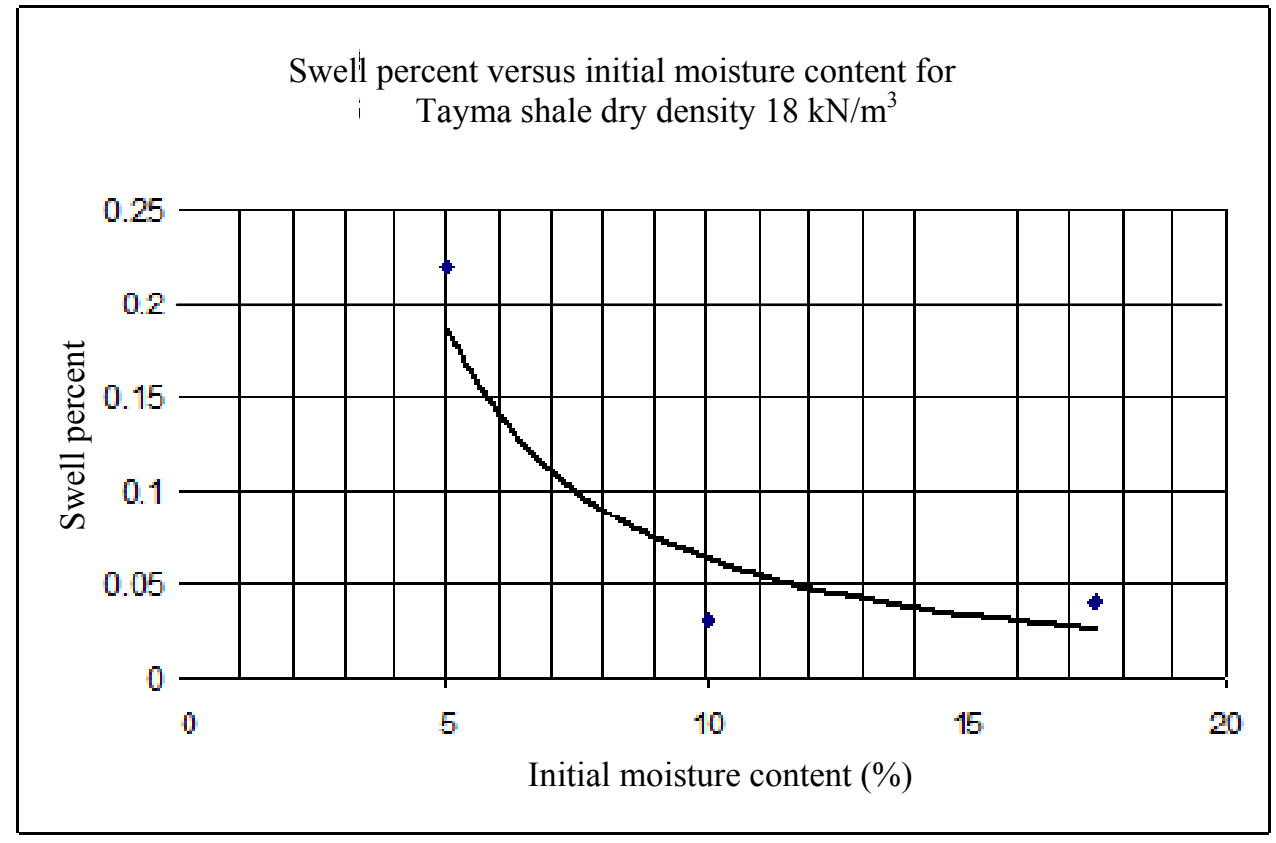

Fig. 5 The swell percent variation with initial molding moisture content.

\section{Results and Discussion}

It needs to be understood that the classification of expansive soils as established by different researchers is mostly based on the physical and mechnical reactions associated with specific material properties. Expansive soil behaviour is sensitive to many parameters and reflects the motion of the active ingradient causing the swell. The fine clay portion ofthe soil is responsible for these groupings. These 


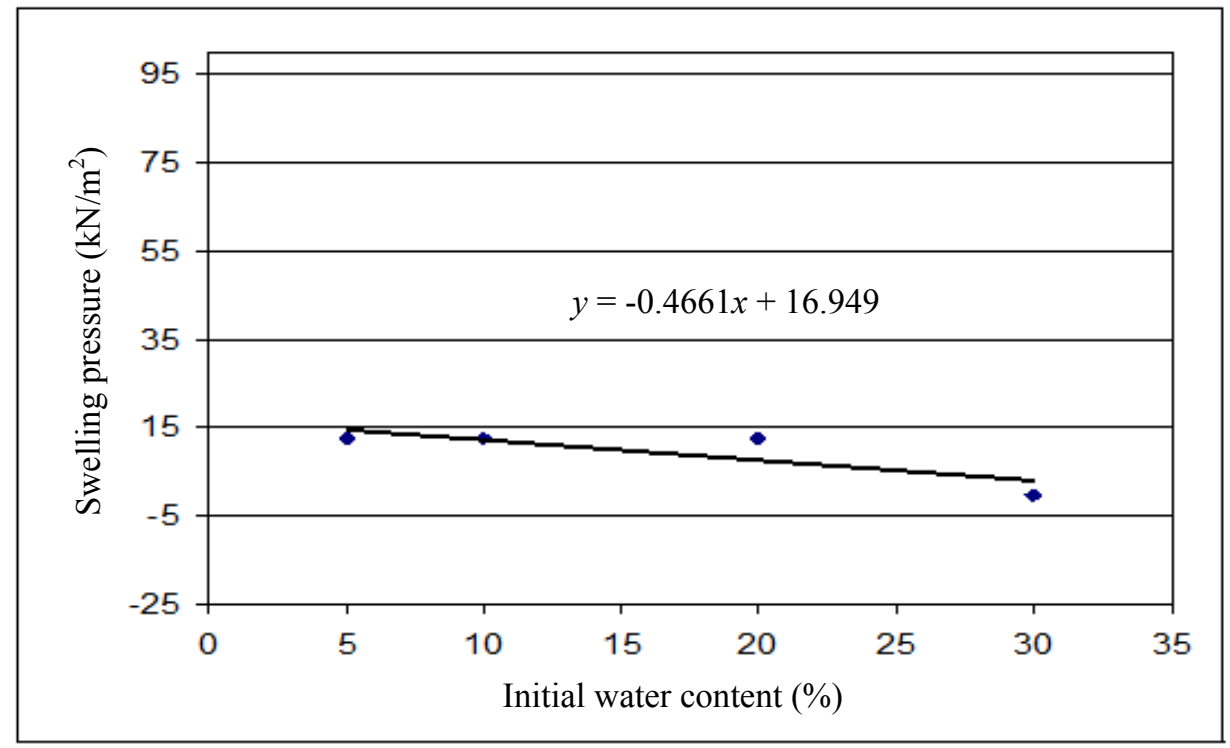

Fig. 6 Measured swelling pressure at different water content values.

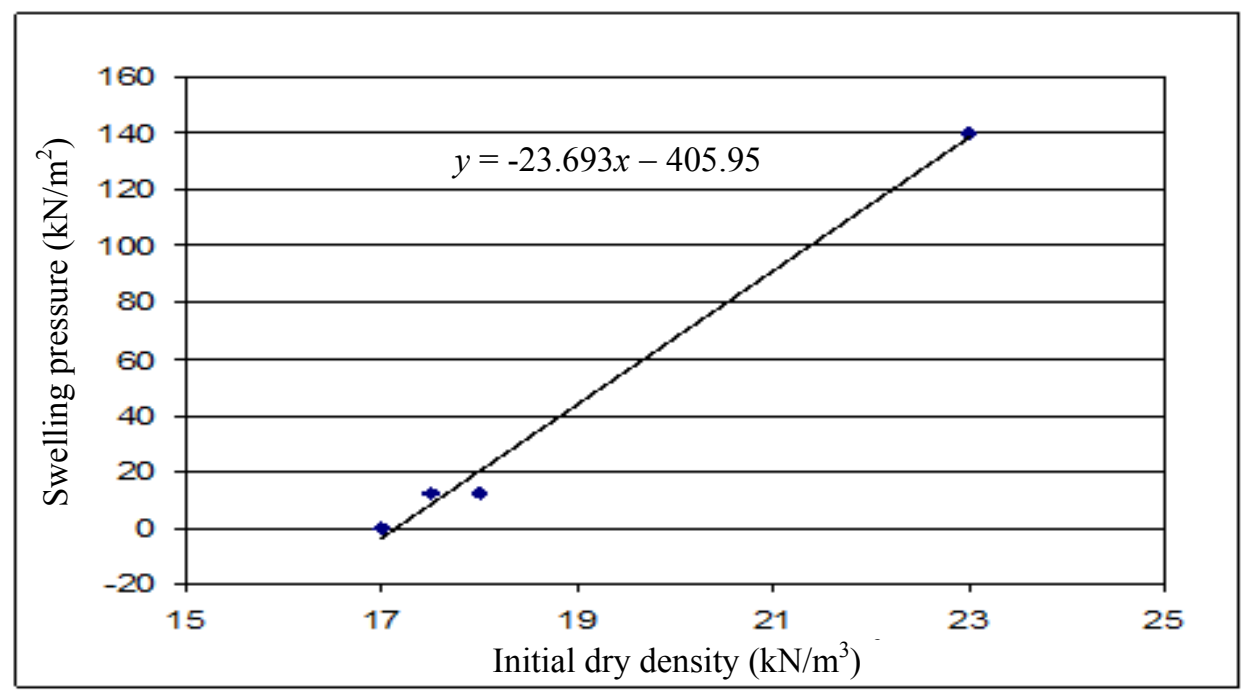

Fig. 7 Measured swelling pressure at different initial dry density values.

classifications may be missleading if not interpretted in view of external environment and subsurface soil conditions. A soil classified as highly expansive with liquid limit in excess of 150 and plasticity index of more than 100 may not give serious damage to light structures within the area (Al Qatif clay) while a soil from Al Qulaiba classified as having low degree of expansion with liquid limit of about 35 and plasticity index of less than 15 gives serious troubles to roads and buildings. The level of confinement applied to the clay portion ( within internal structure and externally) plays a greater role in the development of the swelling pressure or upheaval forces. Tayma soil was found to cause problems to light structure although ranked within low expansion soils. A lesson to be learned from this comparison is not to consider charaterization or classification charts as a quantitative measurie of risk. Only direct measurements or testing conditions simulating the actual field conditions is to be used when specifying swelling parameters. 
The emperical formulas are of local validity and do not apply to soils of different mineralogy. Fig. 8 presents an example of swell developing rate. Swelling pressures obtained for Tayma soils do not match Komornik and David or Nayak and Christensen [9, 10] predictions as indicated in Fig. 9. This is shown to tell practing engineers not to depend on models based on only index properties. Both the purely theoretical approach and the purely empirical approach are found to be inadequate [10]. Direct measurements of the swelling pressure corrected for the site conditions and considered in view of environmental conditions and structures performance history in the area is the appropriate tool to arrive at a reliable design value of the swelling pressure. The swell potential or swell percent is also function of several factors [11] and cannot be taken as an exact quantitative guide. Engineers require knowing how much space needs to

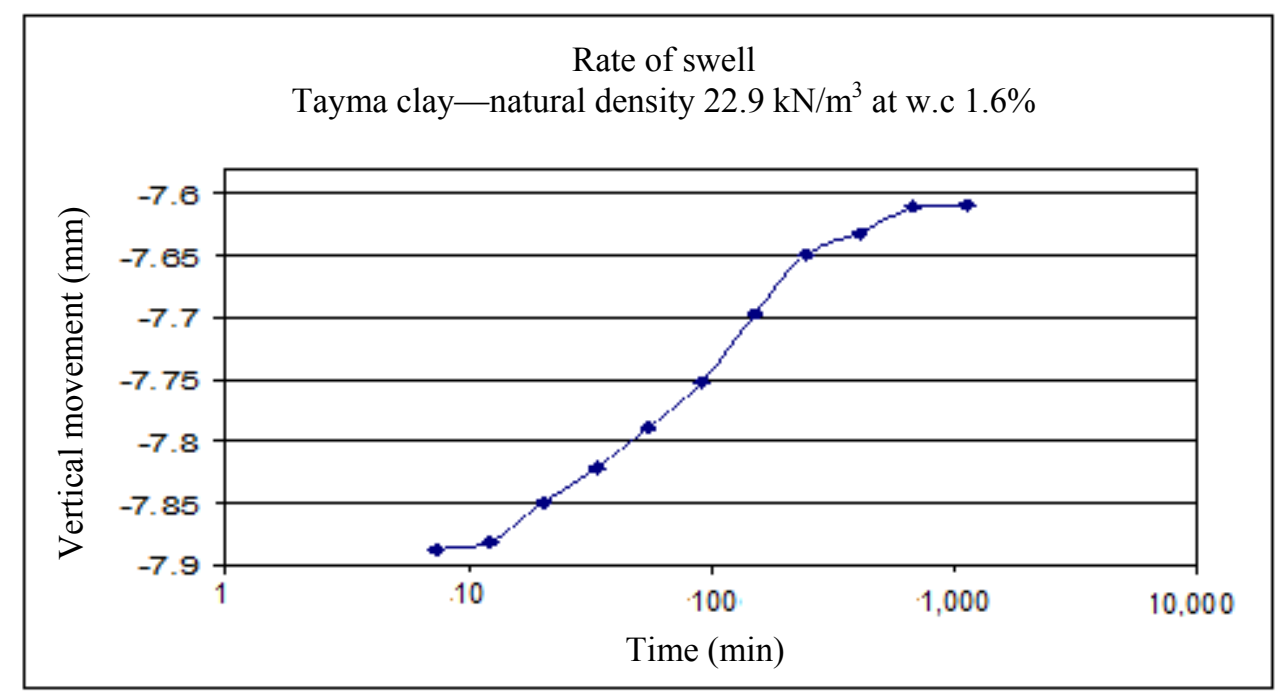

Fig. 8 Example of rate of swell for natural Tayma Shale.

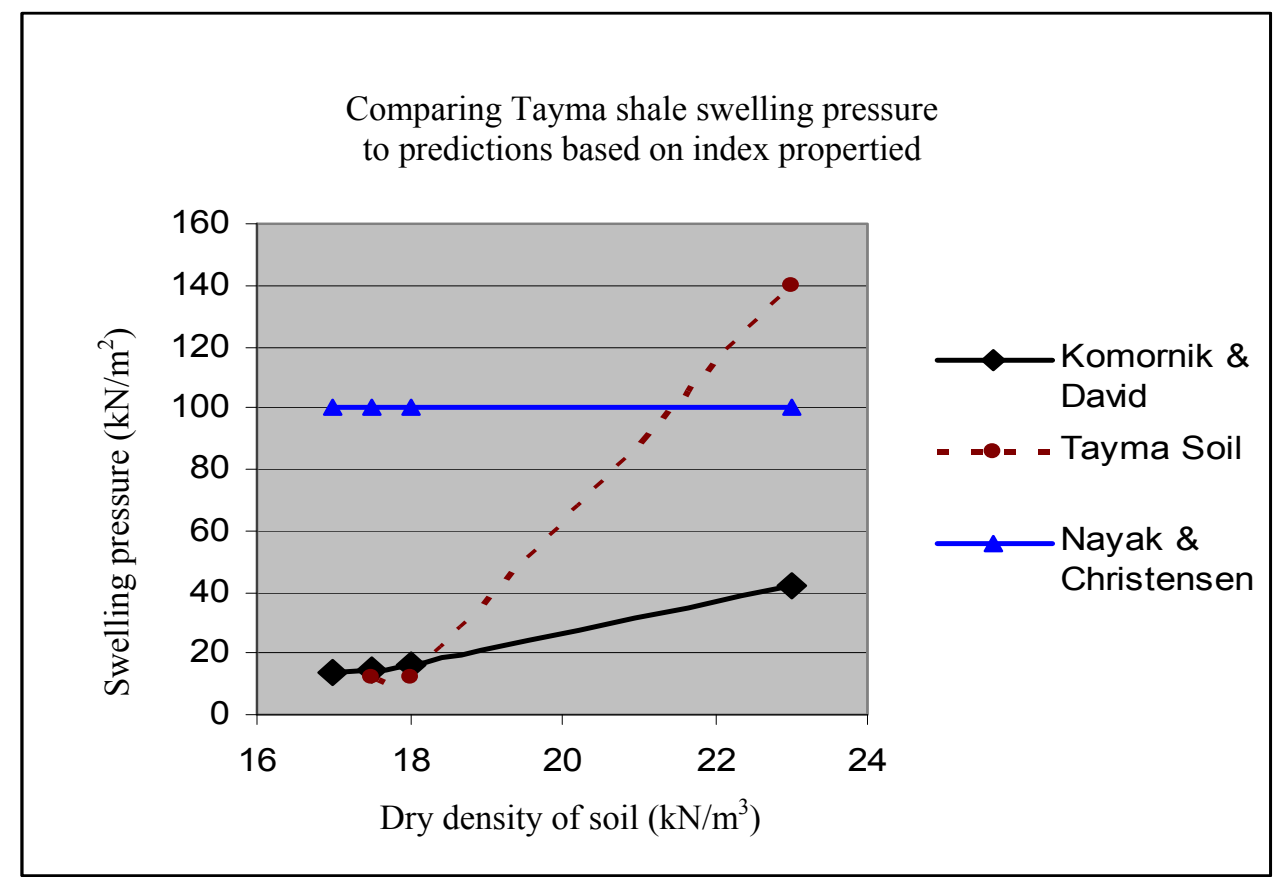

Fig. 9 Comparing Tayma shale measurements to predictions by Komornik, David, Nayak and Christensen [9, 10]. 
be considered when placing a hanging ground beam or slab on grade. This shall also be carefully selected towards the conservative side.

Direct measurements of Tayma shale using one dimensional oedometer testing yielded a compression index $C_{c}$ of 0.177 for a crushed shale compacted at 18 $\mathrm{kN} / \mathrm{m}^{3}$ dry density and a moisture content of $5 \%$. The swelling pressure needed to suppress expansion was $12.5 \mathrm{kN} / \mathrm{m}^{2}$.

The rate of swell was found fast for the first $3 \mathrm{~h}$ and then changes to slow and very slow. The rate of swell is related to the soil density and the rate at which water is entering the sample. When hydration takes place in exterior boundaries, the expansion reduces the permeability and access to inner particles is retarded. Highly expansive soils take very long time to have clay fully hydrated. Fig. 10 presents consolidation curve for compacted Tayma Shale.

The influence of the initial moisture content on the swelling pressure is investigated for Tayma shale crushed samples. Minor reduction on swelling pressure is observed with increasing initial moisture content but this reduction is not very significant. This conclusion is in support of other researchers [5] who claimed that the swelling pressure is independent of the initial water content and upon full hydration a unique swelling pressure is expected.

Increase in dry density is associated with significant increase in the swelling pressure. The density of the laminated clay shale in nature is not uniform and this can vary according to the laminations and bedding spaces. Massive shale of high dry density of $23 \mathrm{kN} / \mathrm{m}^{3}$ is obtained from the site and found to have $140 \mathrm{kN} / \mathrm{m}^{3}$ swelling pressure.

Swelling pressure obtained in a one dimensional oedometer is overestimating the actual value. The standard test method allowing initial free swell of the sample gives 2.3 times higher value than the constant volume method [12]. Al-Shamrani and Dhowian [13] suggested the use of triaxial loading condition in test measurements to allow for the confinement effect or lateral restraint. They found that the compressibility value determined from oedometer measurements was about 3.6 times the value calculated from the field data, whereas based on the results of triaxial swell tests, the ratio of the laboratory to the field value was about 1.3. Works of Taha and Abduljawad [13] covered expansive soils in Al-Madinah not far from Tayma.

For Tayma Shale it is suggested to consider one third of the tested natural undisturbed clay shale. This is $47 \mathrm{kN} / \mathrm{m}^{3}$ and can be rounded to $50 \mathrm{kN} / \mathrm{m}^{3}$. Light

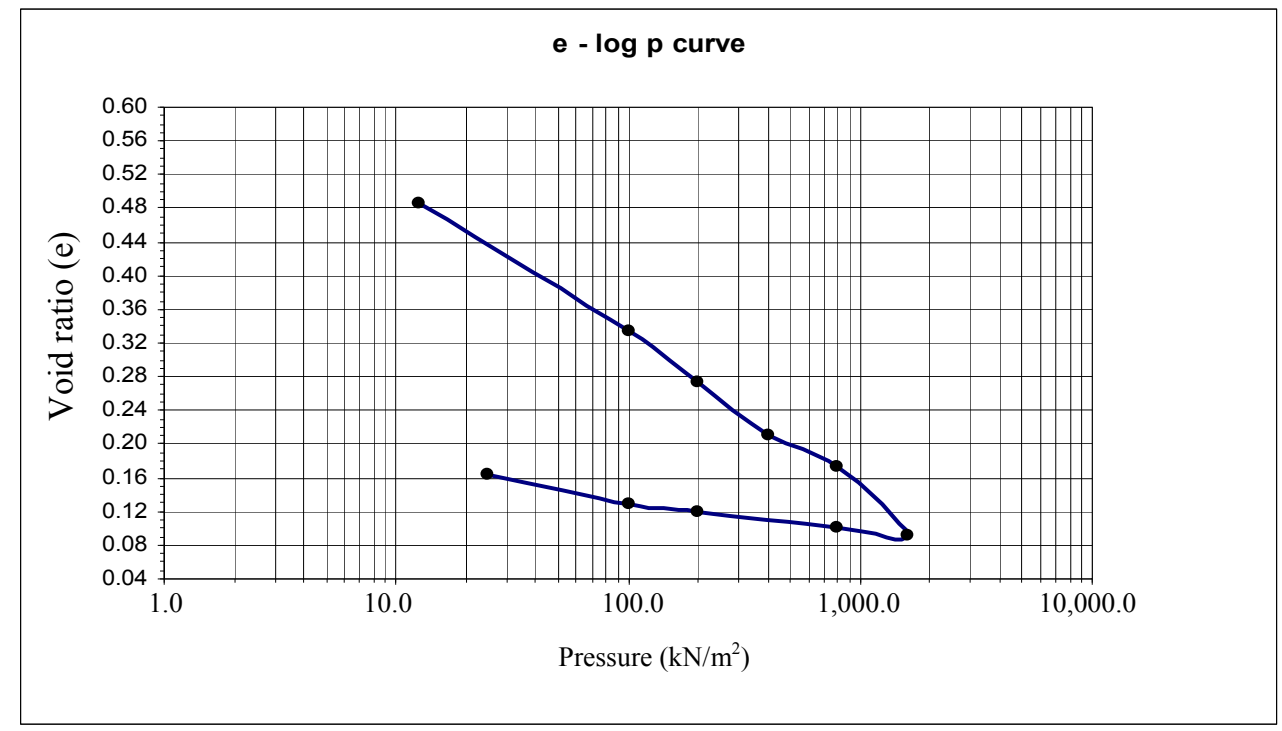

Fig. 10 Consolidation curve for compacted Tayma shale. 
Table 4 Level of damage classification in Tayma.

\begin{tabular}{lll}
\hline Type of construction & Form of damage & Level of damage \\
\hline Two storey villas (main built area) & Nil & No damage \\
One storey villas (main built area) & Variable cracks, hair $(0.1 \mathrm{~mm})$ to medium $(2 \mathrm{~mm})$, diagonal & Medium \\
Boundary walls & Medium wide $(2 \mathrm{~mm})$ to wide $(>10 \mathrm{~mm})$ cracks, diagonal & Severe \\
Pavements & Upheaval and distortion, cracks variable & Medium \\
Slab on grade & Upheaval and distortion, cracks variable sizes & Medium \\
Asphalt pavement & Upheaval and distortion, cracks variable sizes & Low to medium \\
\hline
\end{tabular}

structures with contact pressures of less than 50 $\mathrm{kN} / \mathrm{m}^{3}$ are likely to be at risk. It is advised that foundations for boundary walls, single story structures and any other light structures to be designed for this value of upheaval force.

The damage in Tayma is found medium to severe for the boundary walls, kerbstones, walkways, single storey structures, slabs on grade and pavements. Structures applying concentrated loads higher than 50 $\mathrm{kN} / \mathrm{m}^{3}$ were found more sound and intact.

According to the Municipality of Tayma, the construction contractors showed very limited concerns for the problem in the past. The level of damage (Table 4) was low to medium in general and most people kept maintaining their properties and sealing off cracks. In recent years, the use of water in households increased and water for irrigating green areas is also increased. Leaking of water supply pipes and drainage facilities made the problem worse. No sewage disposal system in Tayma till 2008 and pits close to houses are used to dispose sewage.

In an attempt to deal with the matter some consultants introduced partial soil replacement (Tayma New Hospital) where the ground is over excavated by $600 \mathrm{~mm}$ and two layers of granular structural fill are placed under the foundation. This approach reduces the risk but the main point is that the superstructure pressure applied on the fill is reduced when transferred to the shale.

A better solution for light structures is either to go for $2 \mathrm{~m}$ depth so that the overburden pressure will counter balance the swelling pressure or have the loads concentrated to apply more than $50 \mathrm{kN} / \mathrm{m}^{3}$ on shale, at a foundation level of $1 \mathrm{~m}$ depth. For pavements, applying a surcharge of more than $2 \mathrm{~m}$ is neither economical nor practical. Preventing water from seeping below the pavement can be achieved by good drainage of surface water. This is also applicable for walkways and on ground slabs. Intercepting subsurface water or use of cut off walls can be of help.

\section{Conclusions}

The classification approaches based on routine index properties is made for general guidence only and shall not be used for quantifying the risk. Prediction methods based on index properties are of local validity. Tayma shale was found to behave differently when compared to two swelling pressure prediction equations. Clay soils classified within groups of low degree of expansion can introduce troubles to light structures. Mineralogy study using $\mathrm{x}$-ray diffraction on Tayma shale confirmed the presence of smectite group clay minerals. Direct measurement of undisturbed samples simulating the field conditions is the most appropriate method to deal with expansive soil. Confinement, site environment and performance history of structures within the area shall be taken into account.

The influence of moisture content on the swelling pressure is not significant. Increase in the dry density is associated with the increase in the swelling pressure. Tayma shale is expected to generate an upheaval force on wetting equal to $50 \mathrm{kN} / \mathrm{m}^{3}$. It is suggested to suppress the swelling pressure with superstructure concentrated loads or placing the foundation at a deep level so that overburden pressure can counter balance the swelling pressure. Preventing water from seeping under pavements, walkways or near foundations is 
suggested for Tayma shale. Further studies on typical soils can help in further improvements.

\section{Acknowledgments}

The authors wish to acknowledge BRCES (Bugshan Research Chair in Expansive Soils), King Saud University, for supporting this study and to Engineer Mohammed Al Sharary of King Saud University for performing most of the laboratory testing during his study under the supervision of the authors.

\section{References}

[1] A. Dhowian, O. Erol, Y. Abdulfattah, Evaluation of Expansive Soils and Foundation Methodology in the Kingdom of Saudi Arabia, King Abdulaziz City for Science and Technology, Riyad, 1988.

[2] V.N. Vijayvergiya, O.I. Gazzaly, Prediction of swelling potential for natural clays, in: Proceedings of 3rd International Conference on Expansive Soils, Haifa, 1973, pp. 227-234.

[3] W.G. Holtz, H.J. Gibbs, Engineering properties of expansive clays, Transactions of ASCE 121 (1956) 641-663.

[4] A. Sridharan, K. Prakash, Classification procedures of expansive soils, Proceedings of Institution of civil
Engineers, Geotechnical Engineering $143 \quad$ (2000) 235-240.

[5] F.H. Chen, Foundations on Expansive Soils, Elsevier, Amsterdam, 1975.

[6] Indian Standard Classification and Identification of Soils for General Engineering Purposes, IS 1498, Bureau of Indian Standards, New Delhi, 1970.

[7] Y. Erzin, O. Erol, Swell pressure prediction by suction methods, Engineering Geology 92 (3-4) (2007) 133-145.

[8] M.A. Al-Shamrani, A.I. Al-Mhaidib, Prediction of potential vertical swell of expansive soils using a triaxial stress path cell, Quarterly Journal of Engineering Geology \& Hydrogeology 32 (1) (1999) 45-54.

[9] A. Komornik, D. David, Prediction of swelling potential of clays, Proceedings ASCE 95 (1) (1969) 209-225.

[10] N.V. Nayak, R.W. Christensen, Swelling characteristics of compacted expansive clay, Clays and Clay Minerals 19 (1970) 251-261.

[11] M.O. Taha, S. Abduljawad, Expansive soils in Al-Madinah, Saudi Arabia, Applied Clay Science 7 (4) (1992) 271-289.

[12] E.M. Ali, M.A.D. Elturabi, Comparison of two testing methods of swelling pressure, in: Proceedings of the Fifth International Conference on Expansive Soils, Adeliadem, Australia, 1984.

[13] M.A. Al-Shamrani, A.W. Dhowian, Experimental study of lateral restraint effects on the potential heave, Engineering Geology 69 (2003) 63-81. 